\title{
光学系の基本設計*
}

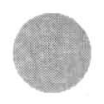

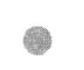

田中 済**

Fundamental Design of the Optical System / Wataru TANAKA

Key words: Subaru Telescope, optical design, optical aberration, primary mirror, secondary mirror, focus

\section{1. 光学設計の基本方針}

すばる望遠鏡は計画段階（当時は大型光学赤外線望遠鏡 と呼んでいた。今でもこの望遠鏡の正式名称である）で は，主鏡の有効径が $7.5 \mathrm{~m}$ （現状 $8.2 \mathrm{~m}$ ）であったことな どから, 光学系の基本設計も多少複雑ななりたちをしてい る.

経緯台式反射望遠鏡にすることは当初からのコンセプト であった．主鏡をどうやって作るか，それをどう支持する かがこの望遠鏡の最大のブレーク・スルーであり，計算や 実験が行われた. 1980 年代の終わりにはほほ仕様がまと まり，薄いメニスカス鏡を 300 本程度のアクチュエータに よって力制御で支えることがきまった．鏡材はコーニング 社の ULE というゼロ膨張ガラスとし, 厚みは $200 \mathrm{~mm}$ と すること, 鏡の軸に平行な方向はアクティブに支持し, 軸 と直角な方向は鏡の裏に穴をあけてローカルな重心をてこ で支えるなどが決まった．主鏡のアクティブ支持について は伊藤氏の記事で詳しく述べられている.

主鏡の焦点距離はきりのよい值として $15 \mathrm{~m}$ とすること にした。いわゆる $\mathrm{F}$ ナンバーは口径 $7.5 \mathrm{~m}$ に対して 2.0 に なる. 焦点としてはカセグレン焦点のほか, 経緯台式望遠 鏡の特徵であるナスミス焦点を $2 つ$ 設ける. 計画されてい る他の新技術望遠鏡にない焦点として主焦点（直焦点）も 設けることになった。 また, 将来より安定した焦点として 干涉計などに使用するためのクーデ焦点が, ナスミス焦点 の延長上にリレー光学系をおくことで設置できる設計に なっている.

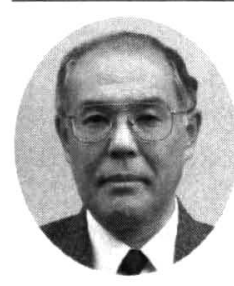

* 原稿受付 平成 13 年 8 月 6 日

** 1939 年生, 1964 年東京大学大学院修士課程修 了, 理学博士. 東京大学理学部助手を経て 1999 年国立天文台教授退官, 専門は観測天体 物理学. 気球・ロケットによる天体観測, すば る望遠鏡建設に従事. 現在, 三菱電機技術コン サルタント．著書：惑星とその観測
図 1 は光学系全体の概念図である.

望遠鏡の性能を表すのに星像の直径で示すのが直感的で ある.すばる望遠鏡では追尾性能も含めてこれを 0.23 秒 角 (FWHM) 以下と規定した. 光学設計では特別な場合 を除いてこれよりはるかに小さい值が求められており, 星 像の悪化は研磨過程の誤差と光学系の支持によって生ずる ことになる。

\section{2 面光学系反射望遠鏡のパラメータ}

カセグレン焦点は主鏡に正対して凸面鏡（副鏡）をお き,ここで光を折り返すとともに焦点距離をのばして主鏡 の裏より先に焦点をむすばせるものである. 光をさえぎら ないように主鏡の中央にはカセグレン穴があけられる。主 鏡面から焦点までの距離（焦点引出し量）はバック・ フォーカスといって重要なパラメータである.

カセグレン系は 2 面光学系反射望遠鏡の代表であるが, ここでそのパラメータがどのように求められるかについて 数式で説明する. パラメータとしては主鏡の曲率半径 $r_{1}$ (これは焦点距離の 2 倍に等しい), 副鏡の曲率半径 $r_{2}$, 主鏡と副鏡の距離 $d$, バック・フォーカス $s$, 合成焦点距 離 $f$ がある。これらの間には次のような関係がある。通 常は $r_{1}, s, f$ を決めて $r_{2}$ や $d$ を求めたいことが多いの でその場合の式を示す. 便宜上 $R=-2 f / r_{1}, \xi=-2 s / r_{1}$ とおくと

$$
\begin{aligned}
& d=-\frac{f(R-\xi)}{R(R+1)} \\
& r_{2}=-\frac{2 f(1+\xi)}{R^{2}-1}
\end{aligned}
$$

ここで注意してほしいのは符号である．光線が入射する 方向を正にとることにする.したがって $r_{1}$ は一般に負で ある. $r_{2}$ もカセグレン系は負, $d$ も負, $s$ や $f$ は正である.

副鏡で反射された光が主鏡に到達する前に 45 度に傾け た平面鏡（第 3 鏡）をおいて光を脇にはねることが考えら れるが，経緯台式望遠鏡では第 3 鏡を高度軸上におけば光 


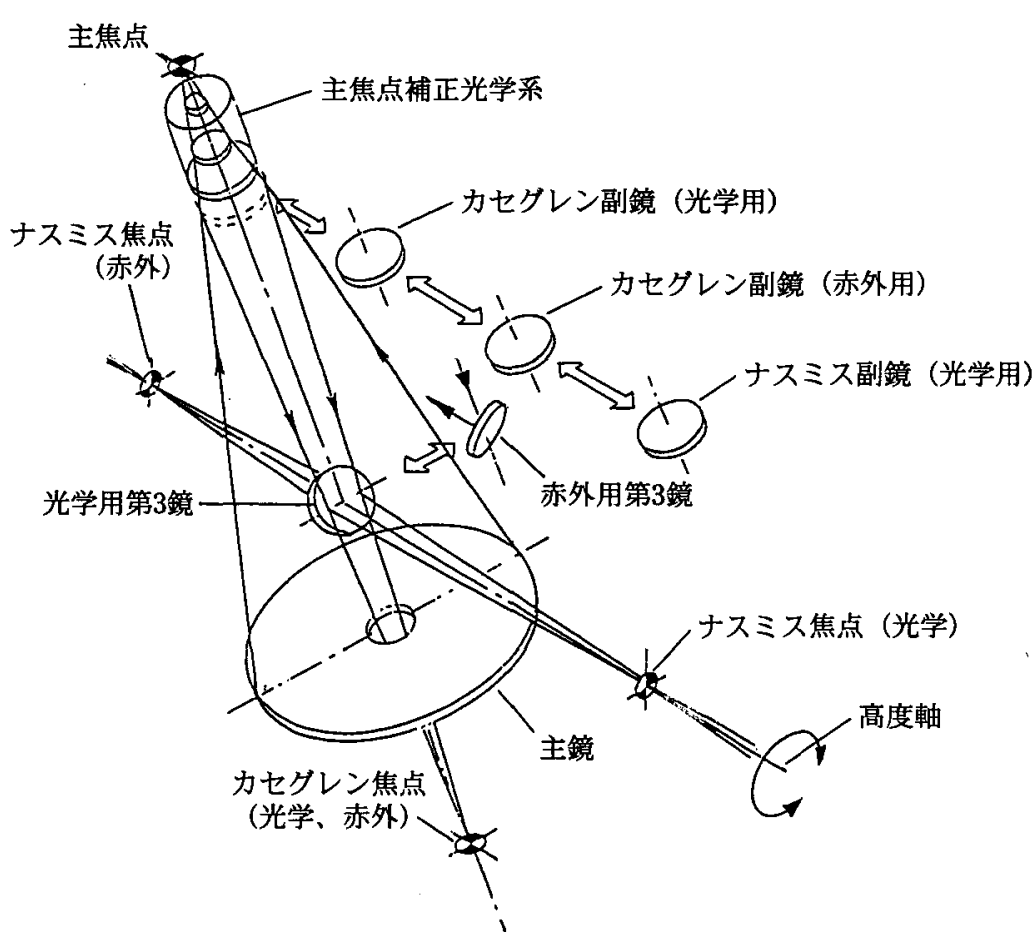

図 1 光学系の概念図. すばる望遠鏡はカセグレン焦点, 光学ナスミス焦 点, 赤外ナスミス焦点, 主焦点の 4 焦点を持ち, 光学カセグレン副鏡, 赤 外カセグレン副鏡 (赤外ナスミス兼用), 光学ナスミス副鏡, 主焦点補正

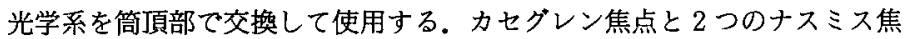
点は中央部の 2 枚の平面鏡（第 3 鏡）を抜き差しして切り替える.

うとするとコマ収差が出てしまう。これを さけるため主鏡も回転双曲面とした光学系 が考えられている。

双曲面といっても放物面に極めて近い面 である. 主焦点は視野中心でも球面収差が 出てしまうがこれは補正光学系でとること にする．補正光学系を設計してみると，主 鏡が放物面より双曲面の汪うがよい補正系 が設計できるようだということがわかっ た。副鏡の回転双曲面は変わらないがより 強い双曲面になる。

光学では面形状を表すのに非球面係数 $b$ というものを使う。一般には 2 次曲線を表 すのに離心率 $e$ が使われるが $b=-e^{2}$ の 関係がある. 名のどおり非球面係数は球面 で0である．棈円面には長軸回転楕円面と 短軸回転棈円面があるが，前者の $b$. 0 とー1の間にあり，後者の $b$ は正の值をと る. 短軸回転棈円面では $e$ を虚数と考元 るわけである.放物面のbはちょうど -1 , 双曲面の $b$ は-1 以下の值をとる.

\section{2 面光学系の収差}

ここで少し難しくなるが光学系の収差に ついて述べる.

は高度軸の中に入ってくる．高度軸を中空にしてその後ろ に棚を作り，その上に観測装置をおけば望遠鏡を振っても 観測装置を上下に振り回さないで斉む。.これをナスミス焦 点といって望遠鏡の左右に 2 力所設けることが出来る。す ばる望遠鏡では望遠鏡が倒れる方向（これを前と考える） から見て右側を主に可視域の観測に使うことにして光学ナ スミス，左側を主に赤外線観測に使うことにして赤外ナス ミスと称する.ナスミス焦点は 45 度の平面鏡が入るが， これは光を曲げているだけであるから本質的には 2 面光学 系である。

主焦点は主鏡の Fナンバーが小さいため収差が大きく そのままでは使い物にならないが，ここに補正光学系をお いて収差を小さくする．補正光学系はレンズと鏡が考えら れるが，すばるでは検討の結果，レンズによる補正光学系 を設計することにし，3枚のレンズでほほ直径 30 分角の 視野が取れることがわかった，補正系こみの焦点距離は $15 \mathrm{~m}$ 上り多少長くなる. 主焦点は 2 面光学系ではないが, 補正光学系をまとめてユニットと考えれば 2 面光学系と類 似点は多い.

カセグレン焦点は出来る限り視野を大きくとるために リッチ・クレティアン系といわ机る光学系をとることにし た. 従来のカセグレン（クラシカル・カセグレン）は主鏡 の形状が凹回転放物面で副鏡は凸回転双曲面である．特徴 は主焦点（主鏡の焦点）でも視野中心は収差がないことで ある. カセグレン焦点も中心は収差がないが，視野をとろ
光学収差にはザイデルの理論というのがあって，収差を 球面収差, コマ収差, 非点収差, 像面湾曲, 歪曲の 5 つに 分類する。これらを詳しく述べるとそれだけで多くの紙面 を費やすことになるが，簡単にいうと，平行光が入射した ときに球面収差は入射瞳（例えば鏡の面）の違う場所を通 過してきた光が焦点に集まらない収差, コマ収差は光軸 （光学面の中心を通って面と直交する直線）からはずれた 光線が彗星のような形の像を結ぶ収差, 非点収差は焦点の 前後で像が縦に伸びたり横に伸びたりする収差, 像面湾曲 は像がもっともシャープになる面が平面にならない収差, 昰曲は文字通り四角いものが糸巻き型や樽型の像になる収 差である。

ザイデルはこれを 3 次式に展開して係数を $B, C, D$, $E, F$ で与えた. $B$ は球面収差に, $C$ と $D$ は非点収差と 像面湾曲に, $E$ は歪曲に， $F$ はコマ収差に対応している。 厄介な式が出て恐縮であるが, 2 面光学系ではこれらは次 のように与えられる，ただし，光学系では入射瞳というも のが大切であるが，すべて主鏡にあると考える．副鏡に瞳 があるとものによっては違った表現になる。ここで $b_{1}$ は 主鏡の， $b_{2}$ は副鏡の非球面係数である.

$$
\begin{aligned}
& B=\frac{1}{r_{1}^{3}}\left[1+b_{1}-\frac{(R-1)^{3}(1+\xi)}{R^{3}(R+1)}\left\{b_{2}+\left(\frac{R+1}{R-1}\right)^{2}\right\}\right] \\
& C=\frac{1}{2 f}\left[\frac{R^{2}+\xi}{R(1+\xi)}-\frac{(R-1)^{3}(R-\xi)^{2}}{4 R^{2}(R+1)(1+\xi)}\left\{b_{2}+\left(\frac{R+1}{R-1}\right)^{2}\right\}\right]
\end{aligned}
$$




$$
\begin{aligned}
& D=\frac{1}{2 f}\left[\frac{\left(R^{2}-1\right)(R-\xi)}{R(1+\xi)}-\frac{(R-1)^{3}(R-\xi)^{2}}{4 R^{2}(R+1)(1+\xi)}\left\{b_{2}+\left(\frac{R+1}{R-1}\right)^{2}\right\}\right] \\
& E=-\frac{\left(R^{2}-1\right)(R-\xi)}{4 R^{2}(1+\xi)^{2}}\left[R+3 \xi+\frac{(R-1)^{2}(R-\xi)^{2}}{2 R(R+1)^{2}}\left\{b_{2}+\left(\frac{R+1}{R-1}\right)^{2}\right\}\right] \\
& F=\frac{1}{4 f^{4}}\left[1+\frac{(R-1)^{3}(R-\xi)}{2 R(R+1)}\left\{b_{2}+\left(\frac{R+1}{R-1}\right)^{2}\right\}\right]
\end{aligned}
$$

収差係数がきまるとこれから具体的な収差の量が計算で きる．望遠鏡の有効径を $a$ ，視野半径を心とすると像の 大きさは,

球面収差 $B a^{3} / 16$ (最小錯乱円)

コマ収差 $3 F a^{2} \tan (\omega / 4)$ (視野半径方向)

像面湾曲 $(2 C+D) a \tan ^{2} \omega$ (視野半径方向)

非点収差 $2 C a \tan ^{2} \omega$

歪曲 $E \tan ^{3} \omega$

で与えられる。

クラシカル・カセグレンではこのうち球面収差のみがゼ 口になる， $B=0$ から条件が出てくるが，通常は $b_{1}=-1$ (放物面) にとって

$$
b_{2}=-4 R /(R-1)^{2}-1
$$

とする。これは一般には－1より小さく双曲面である．実 は副鏡を凹の長軸回転棈円面とすることも可能である．こ れをグレゴリアン系といってカセグレン系では副鏡が主鏡 の焦点の内側にあるがこれは外側にある。

リッチ・クレティアン系では球面収差 $B$ とコマ収差 $F$ をゼロにすることを考える。この場合は

$$
\begin{aligned}
& b_{1}=-\frac{2(1+\xi)}{R^{2}(R-\xi)}-1 \\
& b_{2}=-\frac{2 R\left\{2 R^{2}-(R-1)(1+2 \xi)\right\}}{(R-1)^{3}(R-\xi)}-1
\end{aligned}
$$

であって，すでに述べたようにどちらも双曲面である。

主鏡副鏡間の距離の自由度やバック・フォーカスの自由 度をなくしてもよいとすると非点収差や歪曲をなくすこと も可能になるが，副鏡が主鏡より大きくなったり焦点が光 学系の中に出来たりして実用になるとはいいがたい. 歪曲 は天体観測では一般に画像処理でとることができるので， 主焦点の補正系では像面湾曲をとることを重要視して歪曲 を許容している。

一方, リッチ・クレティアン系はかなりきつい像面湾曲 が残っている。像面の平均曲率半径は $1 / 2(C+D)$ で計 算されるが,すばる望遠鏡ではカセグレン焦点が 2.41 $\mathrm{m}$, ナスミス焦点が $2.62 \mathrm{~m}$ となっている.ついでに述べ ると両焦点の非点収差は視野半径 3 分角のところで 0.08 秒角程度, 歪曲は 0.001 秒角程度である。

\section{4. 具体的な光学設計（主鏡有効径 $8.2 \mathrm{~m}$ 化に 伴う問題)}

カセグレン焦点では肝心な焦点距離（合成焦点距離）を いくらにするかは議論になった。Fナンバーでいうと既存
の外国の望遠鏡でリッチ・クレティアン光学系を採用した ところはF8が多い.しかし F8にすると副鏡の直径が大 きくなる。これは副鏡を作るのに困難をきたすのみなら ず，その影でせっかくの大口径が損をする．また焦点ス ケールも大きく取りたいということで焦点距離 $90.0 \mathrm{~m}$ (F12.0) にすることになった. バック・フォーカスは機械 的な要請から $3.0 \mathrm{~m}$ にした. 視野は直径 6 分角を確保する.

ナスミス焦点は機械的な要請からバック・フォーカスを $4.6 \mathrm{~m}$ にするとになった。主鏡の形状が決まっていて バック・フォーカスが与えられてしまうと, リッチ・クレ ティアン系の要請からナスミス焦点の焦点距離は一義的に 決まってしまう。副鏡は $r_{2} や b_{2}$ の違うものが必要であ 万.

すばる望遠鏡の予算がついたのは 1991 年度であるが,

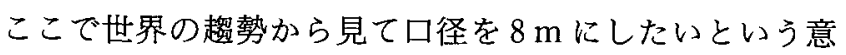
見が強くなった，世界最大をめざすことで有効径 $8.2 \mathrm{~m}$, 外径 $8.3 \mathrm{~m}$ が考えられた。しかし，このまま単純にスケー ル・アップすると，すでに設計が進んでいた機械系やドー ムを大きくしなければならなくなり予算的にも厳しくな る.そこで主鏡の焦点距離の $15.0 \mathrm{~m}$ （曲率半径 $r_{1}=-30.0$ $\mathrm{m}$ ，マイナスは光線が来る方向に対して凹であることを示 す）やバック・フォーカスは変えないこととした．鏡材の 厚みの $200 \mathrm{~mm}$ も変えない. アクチュエータの本数も 300 本を越えることになるので，乙れも鏡面精度の見直しをし て 264 本とし，このうち 3 本を固定点とすることにした。

ここで最大のとばっちりを受けたのが主焦点である.か なりよい線まで設計がなされていた 3 枚レンズでは，収差 のない視野が 24 分に減ってしまうことがわかった．観測 者からは視野の減少は絶対に困るという要望があって苦慮 を強いられたが, 幸いキャノンの武士さんの設計で, レン ズの枚数は増えるが視野直径 30 分角がとれることが示さ れた。地球に大気が存在するために天体が浮きあがって見 える大気差という現象があり，その浮き上がり方が光の波 長によって違うために天体が虹のように見える大気分散と いう現象が起こる．大気差や大気分散は天体の高度が低い と顕著になるが，それを打ち消すために大気分散補正系と いうものを赤外ナスミスを除いた各焦点に組み込むことに していた，武士さんの設計はこの分を増えた補正光学系レ ンズに含ませることで実質レンズの枚数を同じにすること に成功している.この補正系について詳しいことは横田秀 夫氏の記事（p.1575）を参照されたい.

すでに設計の進んでいる観測装置に配慮してカセグレン 焦点のFナンバーは変えないことにしたが, 合成焦点 距離はきりのよい $100.0 \mathrm{~m}$ にすることとし Fナンバーは 12.195122 になった。

経緯台式望遠鏡では視野の回転がおこるが, カセグレン 焦点はインストルメント：ロデータというもので，観測装 置全体を回転させてこれを打ち消している.ナスミス焦点 では観測装置を回転させず像の方を回転させるイメージ・ ロテータを使用する。イメージ・ロテータで最も広く採用 


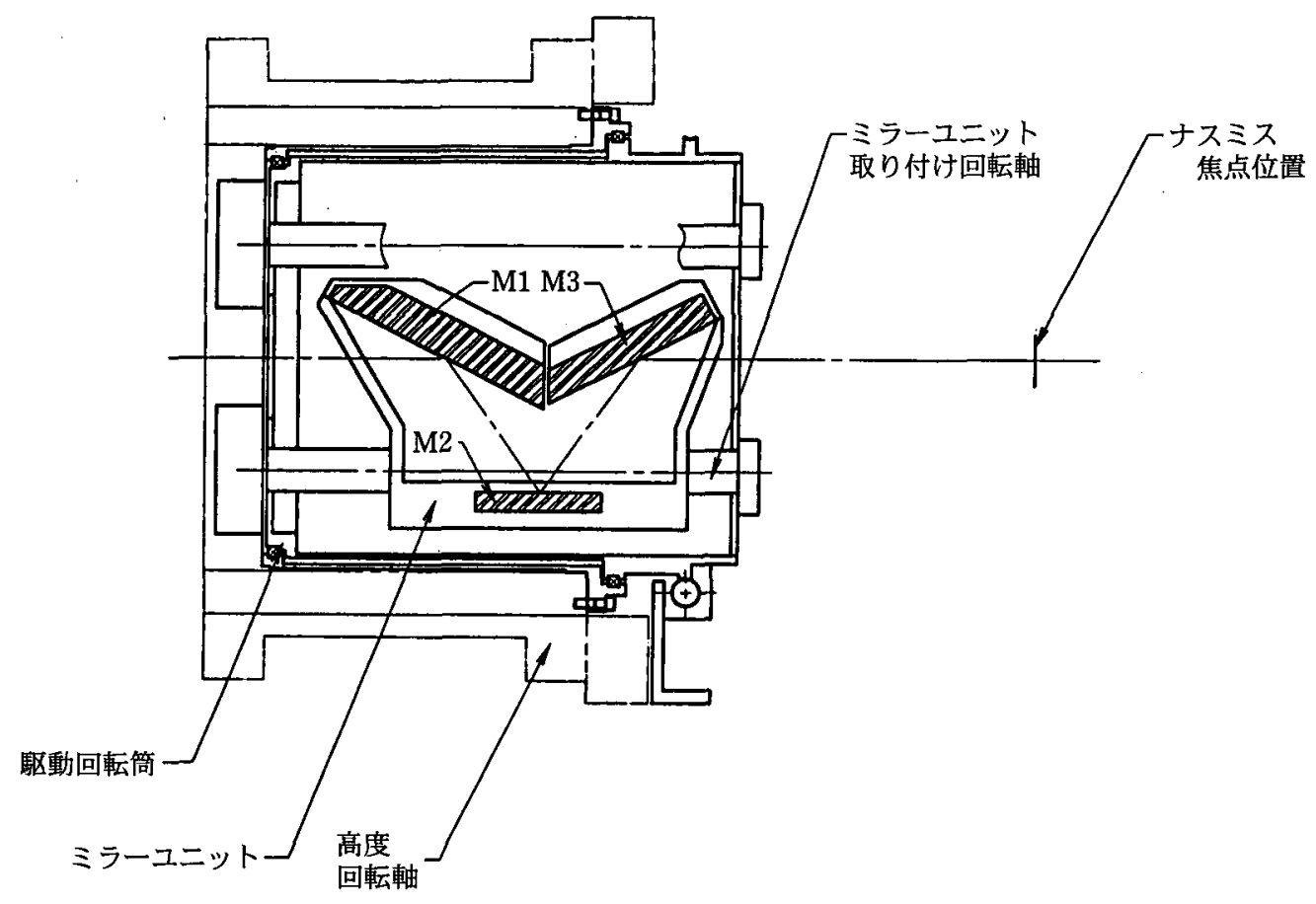

园 2 イメージ・ロテータの断面図. 3 枚の平面鏡を図のように配置して 軸の周りに回転させると像が回転して見える.像の回転角は軸の回転角の 2 倍になる。像が裏返しになること, 光路長が伸びることに注意する。

されているものは図 2 に示すような平面鏡を 3 枚組み合わ せたものであるが，このために光路長が $0.3926 \mathrm{~m}$ 伸びる ことがわかった。議論の結果, イメージ・ロテータを挿入 したときのバック・フォーカスを $4.9926 \mathrm{~m}$ とし，この状 態でナスミス焦点がリッチ・クレティアンの条件を満たす ように光学設計することになった。ロテータなしではバッ ク・フォーカスが本来の $4.6 \mathrm{~m}$ になり, 同じ副鏡ではもは やリッチ・クレティアン系にはならないが，その差はわず かであって我慢する（視野半径 3 分角でのコマ収差が 0.06 秒角)。十スミス焦点の視野直径はイメージ・ロテータな しではカセグレン焦点と同じ 6 分角であるが，ロテー夕使 用時は 3.5 分角に減少する.

\section{5. 副鏡枚数のオプティマイズ}

この望遠鏡は可視域と赤外線の両方で使うため, 焦点距 離は同じでもそれぞれ別の副鏡が要る. 可視用（光学用） は光量を損せずに視野をとるために大きな副鏡を使用する のに対して，赤外用は余計なところを見るとバックグラウ ンドが增えるので小さな副鏡を使用する．可視用では瞳が 主鏡にあるのに対して，赤外用では瞳は副鏡にある．赤外 観測では視野とバックグラウンドを両立させるため光量を 損することは我慢する。表面のコーティシグも可視用は特 に紫外域の反射率のためにアルミニウムにするが，赤外用 は反射率のために銀や金をコーティングする。しかし，こ うしていくとカセグレンで 2 枚, ナスミスで 2 枚, それに 主焦点補正系がある。さらに中間赤外用に F 35 の副鏡や 赤外用の主焦点補正系も考光られていた。それら 7 つを交
換することを考えると気が遠くなりそうになる。

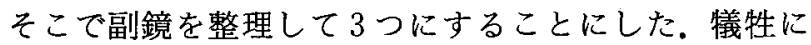
なったのは赤外ナスミス副鏡で赤外カセグレン副鏡と共用 にする。そうするとりッチ・クレティアン系にならなくな る.コマ収差はよいことにしても中心での球面収差が問題 になるが，これは主鏡がアクティブ・サポートなので，そ の非球面定数を変えて対処する．具体的には主鏡の緑で 1 $\mu \mathrm{m}$ ほど曲げることになる，コマ収差が残るが，赤外線は 条件がゆるいのとナスミス焦点でイメージ・ロテータを使 用した場合は視野が狭いのであまり問題にならない（視野 半径 1 分角に扔けるコマ収差は 0.11 秒角)。ただし, 焦点 位置を伸ばすために副鏡の位置をかなり主鏡に近づける必 要が生ずるので，合焦機構の可動範囲を大きくした。,ナス ミス焦点のイメージ・ロテータなしのときも，きわめてわ ずかであるが主鏡を変形させて球面収差をとっている.

これにはメリットもある．副鏡を交換するのは 1 日作業 であり，交換するとポインティング・アナリシス（望遠鏡 指向方向の誤差解析）が必要になって貴重な夜がつぶれ る. 副鏡が共通であればナスミス焦点とカセグレン焦点の 切り替えはナスミス第 3 鏡（45 度鏡）のみになる。第 3 鏡は 30 分から 1 時間で交換でき，ポインティング・アナ リシスもいらない. 可視ナスミス焦点も観測装置の高分散 分光器の視野は 1 分角と狭いのでコマ収差はあまり問題に ならない。もし可視カセグレン副鏡の合焦範囲が大きく とってあれば，同じメリットを受けられるはずでそうしな かったことが悔やまれる。

こうして決まった光学系の設計值を表 1 に示す．与えら 


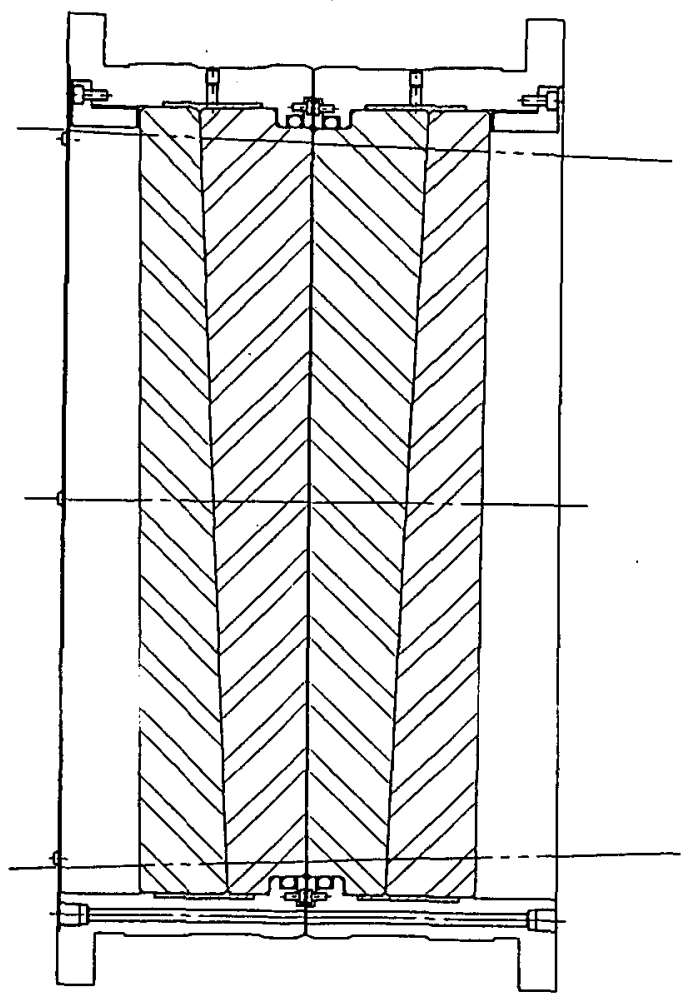

图 3 大気分散補正系の断面図. 頂角の小さなプリズムによって逆 に分散をかけて打ち消すのであるが，光軸が折れ曲がっては困るの で届折率がほほ同じで分散の異なる光学ガラスでプリズムを作り組 み合わせる。高度角によって大気分散が変化することに対応するた め, 同じ組み合わせを $2 つ$ 作ってお互いに軸の周りに回転させるこ とで分散量を調節する. ガラスの厚みによって光路長が少し伸びる.

れた值は主鏡の曲率半径 $r_{1}$, カセグレンの合成焦点距離

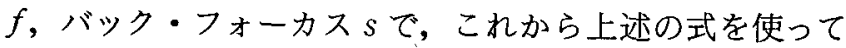
主鏡の非球面定数 $b_{1}$, 副鏡の曲率半径 $r_{2}$, 非球面定数 $b_{2}$, 主鏡副鏡間の距離 $d$ が計算される. 焦点によって, またイメージ・ロテータが入るかどうかによって, 副鏡や バック・フォーカスが変わり多くの組み合わせができてし まう. 実は大気分散補正系 (図 3 参照) が入ると光路長が 伸びるため光学定数は微妙に変わるが，わずらわしくなる ので，ここではビルトインされていてそれをはずすことが できない主焦点を除いて，大気分散補正系なしの定数を示
す.

\section{6. 光学定数に対する研磨誤差の影響}

実際の光学定数は研磨が完全でないため設計通りにはな らない．製作誤差が大きいと収差も増えるが，もっとも大 きく影響を受けるのは望遠鏡機械系である，主鏡の曲率半 径が子定より大きくなると焦点位置が伸びて副鏡の位置を 主鏡から遠ざけなければならず，すでに製作にかかってい る鏡筒を長くしなければならない。これが誤差に対する もっとも笽しい条件である。

実際. 主鏡の曲率半径は-30.00456 m, 非球面定数は -1.00934 , 可視カセグレン副鏡の曲率半径は-5.52419 $\mathrm{m}$, 非球面定数は一1.91608 となった. バック・フォーカ スの $3.0 \mathrm{~m}$ は変えられないので,これから主鏡と副鏡の距 離がー $12.65444 \mathrm{~m}$, 合成焦点距離が $100.02916 \mathrm{~m}$ となる. 副鏡の位置が $2 \mathrm{~mm}$ ほど後退するがこれは許容範囲であ る.収差のうち球面収差はなにもしないと 0.29 秒角も出 てしまうので，主鏡のアクティブ・サポートでとる。その 非球面定数はー1.0082456 となるはずである。コマ収差は 残るが視野の端（カセグレンの視野半径 3 分角）で 0.003 秒角ときわめて小さい. 他の光学系の製作誤差もきわめて 小さく問題になるようなことは生じなかったので，いちい ち詳しく述べることはしない。

主鏡，副鏡は共に回転双曲面であるが，研磿㢣差のため その回転軸と形状の中心とは一致しない. 主鏡と光学カセ グレン副鏡ではこのずれは $2 \mathrm{~mm}$ 活どであった。すばる 望遠鏡では，このずれは副鏡の位置を少しずらして補正す る.他の 2 つ副鏡では, ずれはきわめて小さかった。

収差に対しては光学面の研磨精度の方が影響が大きい が，すべて仕様值よりかなりよく仕上がった，研磨精度の 仕様をどう決め，どうやってそれを実現したかについては 斎藤氏の記事（p.1567）を参照されたい。また観測時は， 望遠鏡の姿勢や温度環境などによって変化する主鏡の形状 をいかに検出して，それをどうアクティブ・サポートに反 映するかが重要であるが，これも伊藤氏の記事（p.1572） を参照されたい.

表 1 光学定数の設計值

\begin{tabular}{ll|r|r|r|r|r|r}
\hline & & $s$ & $b_{1}$ & $r_{2}$ & \multicolumn{1}{c|}{$b_{2}$} & $d$ & $f$ \\
\hline カセグレン焦点 & & 3.0000 & -1.0083505 & -5.5242967 & -1.917322 & -12.652174 & 100.00000 \\
光学ナスミス焦点 & あり & 4.9926 & -1.0083505 & -5.8774200 & -1.865055 & -12.484300 & 104.20700 \\
& なし & 4.6000 & -1.0061375 & -5.8774200 & -1.865055 & -12.492420 & 102.24450 \\
赤外ナスミス焦点 & あり & 4.9926 & -1.0196626 & -5.5242967 & -1.917322 & -12.612447 & 110.60519 \\
& なし & 4.6000 & -1.0175467 & -5.5242967 & -1.917322 & -12.619672 & 108.51239 \\
主焦点 & -15.0631 & -1.0083505 & & & & 15.31805 \\
\hline
\end{tabular}

長さの単位は $\mathrm{m}$. バック・フォーカス $s$ (主焦点では焦点位置), 主鏡非球面定数 $b_{1}$ (アクティブ補正値), 副鏡曲率半径 $r_{2}$, 副鏡非球面定 数 $b_{2}$, 主鏡副鏡間の距離 $d$, 合成焦点距離 $f$. カセグレン焦点は光学, 赤外共通.ナスミス焦点て「あり」, 「なし」はイメージ・ロテータ「あ り」,「なし」を示寸. 主鏡の曲率半径 $-30.0 \mathrm{~m}$, 有効径 $8.2 \mathrm{~m}$, 副鏡の有効径は光学カセグレン $1.33 \mathrm{~m}$, 赤外カセグレン (赤外ナスミス兼用) $1.265 \mathrm{~m}$, 光学ナスミス $1.4 \mathrm{~m}$. 